\title{
Odnos prebivalcev obremenjenih območij do okolja in okoljskih problemov na vzorčnih primerih Šaleške doline in Zasavja
}

\author{
Matjaž Šalej \\ ERICo Velenje, Inštitut za ekološke raziskave, Koroška 58, \\ 3320 Velenje, Slovenija \\ e-mail: matjaz.salej@erico.si
}

\section{Izvleček}

Članek namenja pozornost odzivu prebivalstva na okoljske probleme $v$ Šaleški dolini in Zasavju. Osnova raziskave je bil vprašalnik, s katerim smo anketirali 1395 prebivalcev obeh regij. Glavni cilj prispevka je ugotoviti intenziteto obremenjenosti okolja, kot jo vidijo anketirani in primerjava odzivov na okolje in okoljske probleme med prebivalci obeh regij. Prebivalci Šaleške doline so do onesnaževanja zelo kritični in so s svojim okoljem večinoma zadovoljni $(62,4 \%)$. V Zasavju so prebivalci s svojim okoljem manj zadovoljni (39,5\%), tudi zaradi tega, ker je njihovo okolje glede na slovenske razmere še vedno nadpovprečno obremenjeno.

Ključne besede: degradacija okolja, odziv prebivalstva na življenjsko okolje, zaznavanje okoljskih problemov, Šaleška dolina, Zasavje

\section{Inhabitants' Response to the local Environment and its problems in the case of the Šalek Valley and the Zasavje Region}

\begin{abstract}
In this article we focused attention on the inhabitants' response to the environmental problems in Šalek Valley and Zasavje Region. We used a questionnaire to survey the answers of 1395 inhabitants in both regions. The main aims of our study were following: to estimate the pollution severity and environmental conditions and to compare the answers between both. The inhabitants of the Salek Valley are very critical toward their environment and they are basically satisfied with it $(62,4 \%)$. In the Zasavje Region the inhabitants are less satisfied $(39,5 \%)$ with their environment, because the pollution of their region is larger than average in Slovenia.
\end{abstract}

Key words: Environmental degradation, Inhabitants' response to their environment, Perception of Environmental problems, Šalek Valley, Zasavje Region 


\section{UVOD}

Šaleška dolina in Zasavje sta bila v preteklih desetletjih med okoljsko najbolj obremenjenimi pokrajinskimi deli Slovenije. V obeh regijah predstavljata premogovništvo in elektroenergetika nosilno gospodarsko dejavnost in tudi obe dejavnosti spreminjata kvaliteto in fiziognomijo regij z emisijami nevarnih dimnih plinov, pepela in drugih produktov, ki nastanejo pri pridobivanju termoenergije ter s spreminjanjem reliefa zaradi montanogenega ugrezanja površja. S pojmom Šaleška dolina v ožjem smislu je mišljena dolina oz. kotlina ob srednjem toku reke Pake, med naselji Velenje in Topolšica. Naravnogeografska meja (hidrološka, geomorfološka) Šaleške doline v ožjem pomenu se dobro ujema z zunanjimi mejami sosednjih občin Velenje in Šoštanj. V širšem smislu je z izrazom Šaleška dolina mišljena poleg obeh občin tudi občina Šmartno ob Paki. Ta občina ob spodnjem toku Pake reliefno ne sodi v Šaleško dolino, je pa povezana z Velenjem in Šoštanjem. Nekoč je bila del večje občine Velenje, danes pa sodi v njeno upravno enoto. S pojmom Zasavje je mišljeno območje občin Hrastnik, Trbovlje in Zagorje. Te občine tako v družbenem kot naravnogeografskem pogledu predstavljajo pokrajinsko središče regije.

V Šaleški dolini (manj v Zasavju) so bili v preteklih 15 letih storjeni pomembni koraki pri izboljšanju stanja naravnega okolja z okoljskimi sanacijami naših največjih termoenergetskih objektov (TEŠ, TET). Vzporedno s sanacijo se je oblikovalo vedenje in znanje o okolju in okoljskih problemih, povezanih s temi objekti.

V razvoju znanosti bi težko našli temo, ki je bila $\mathrm{v}$ zadnjih treh desetletjih pogosteje proučevana kot »okolje« in vse, kar je povezano z negativnimi učinki njegovega čezmernega obremenjevanja, onesnaževanja, skratka razvoja, ki ni (bil) uravnotežen z naravo in njenimi zakonitostmi delovanja. Poleg pokrajinskih učinkov človekovih posegov v okolje nas vse bolj zanimajo tudi posredni vplivi degradiranega okolja na človeka oz. posamezne skupine ljudi, ki različno razumejo, zaznavajo in sprejemajo pojave v pokrajini (Špes, 1997).

Spremljanje odnosa prebivalstva do stanja okolja se je z dvigom okoljske zavesti ter s pojavom civilnih in političnih okoljskih in zelenih gibanj $\mathrm{v}$ zadnjih nekaj desetletjih močno povečalo. V Šaleški dolini so se pričele podobne raziskave izvajati v okviru strokovnih prispevkov, ocen stanja okolja in javnomnenjskih raziskav za naročnike na inštitutu za ekološke raziskave, v Zasavju je bilo nekaj posamičnih raziskav opravljenih že prej.

$\mathrm{V}$ raziskavah smo zaznali nekaj pomembnih dejavnikov, ki so vplivali na odnos prebivalstva do okoljskih vprašanj. Njihov vpliv smo lahko opazovali tudi v odzivih anketiranih. Ti dejavniki javnega mnenja, ki oblikujejo odziv anketiranih na okoljsko problematiko, so: prizadetost okolja in ljudi, strah pred 
neznanim, pozitivna naravnanost, informiranost, tradicionalnost okolja in usmerjenost $\mathrm{v}$ prihodnost.

$\mathrm{Z}$ metodo anketiranja smo v preteklih štirih letih opravili deset raziskav, ki so odkrivale javno mnenje prebivalcev Šaleške doline (občine Velenje, Šoštanj in Šmartno ob Paki) in Zasavja (občine Trbovlje, Hrastnik in Zagorje ob Savi) do najpomembnejših okoljskih problemov in vprašanj.

\section{METODOLOGIJA}

Pri sestavljanju ankete smo upoštevali uveljavljena strokovna geografska in sociološka načela. Vprašalniki so bili v večini raziskav razdeljeni na tri dele. V prvem delu smo anketirane spraševali po osebnih podatkih. Zanimali so nas socialno-geografski kazalci (filtri). (Špes, 1998). Ti filtri so različno prepustni za vplive iz okolja in informacije o njem. Vplivajo na sprejemanje, selekcioniranje in zavračanje vplivov in informacij o okolju oz. na njegovo zaznavo. V anketi smo anketirane povprašali po naslednjih kazalcih: starost, spol, izobrazba, narodnost, stalno prebivališče, tip bivališča, v nekaterih anketah še standard in čas bivanja $v$ naselju. Vzorec naj bi bil čim bolj podoben prebivalstveni strukturi tega območja.

V drugem sklopu smo povpraševali po odnosu, zaznavanju in sprejemanju okolja in okoljskih problemov, stanju okolja po naravnih elementih, pri skoraj vseh pa je zadnji del vprašalnika predstavljal odnos prebivalcev do specifičnih problemov, ki zadevajo njihovo ožje bivalno in delovno okolje. Ta sklop vprašanj je predstavljal jedro posameznih raziskav in daje težo temu prispevku.

Zaključni sklop vprašanj se je glede na zahteve naročnika nanašal na specifično dejavnost podjetja. Dobljeni rezultati so bili tudi podlaga za pripravo nadaljnjih razvojnih programov, povezanih $\mathrm{z}$ varovanjem okolja $\mathrm{v}$ podjetjih.

Anketna vprašanja so bila odprta in zaprta. Prevladovala so zaprta, kjer smo ponudili odgovore, nekaj je bilo tudi odprtih vprašanj, kjer so anketirani lahko izrazili svoje mnenje in oblikovali ideje. Odprta vprašanja smo izpostavili kot izkustveni odnos anketiranih in njihov psihosocialni odziv na problematiko.

V letih od 1997 do 2002 je bilo na območju Zasavja in Šaleške doline opravljenih 1395 anket, od tega 412 v Zasavju ter 983 v Šaleški dolini. Anketirali smo v občinah Velenje, Šoštanj, Šmartno ob Paki, Trbovlje, Hrastnik in Zagorje ob Savi. Vzorec anketiranih je bil naključen, anketirane so bile osebe, starejše od 16 let (razen v primeru osnovnošolcev 6. in 8. razredov; Šalej, 1999), anketarji so skrbeli, da je bilo razmerje anketiranih moških in žensk približno enako. 
Matjaž Šalej / Dela 18 • 2002 • 387-399

Preglednica 1: Značilnosti vzorca opravljenih anket

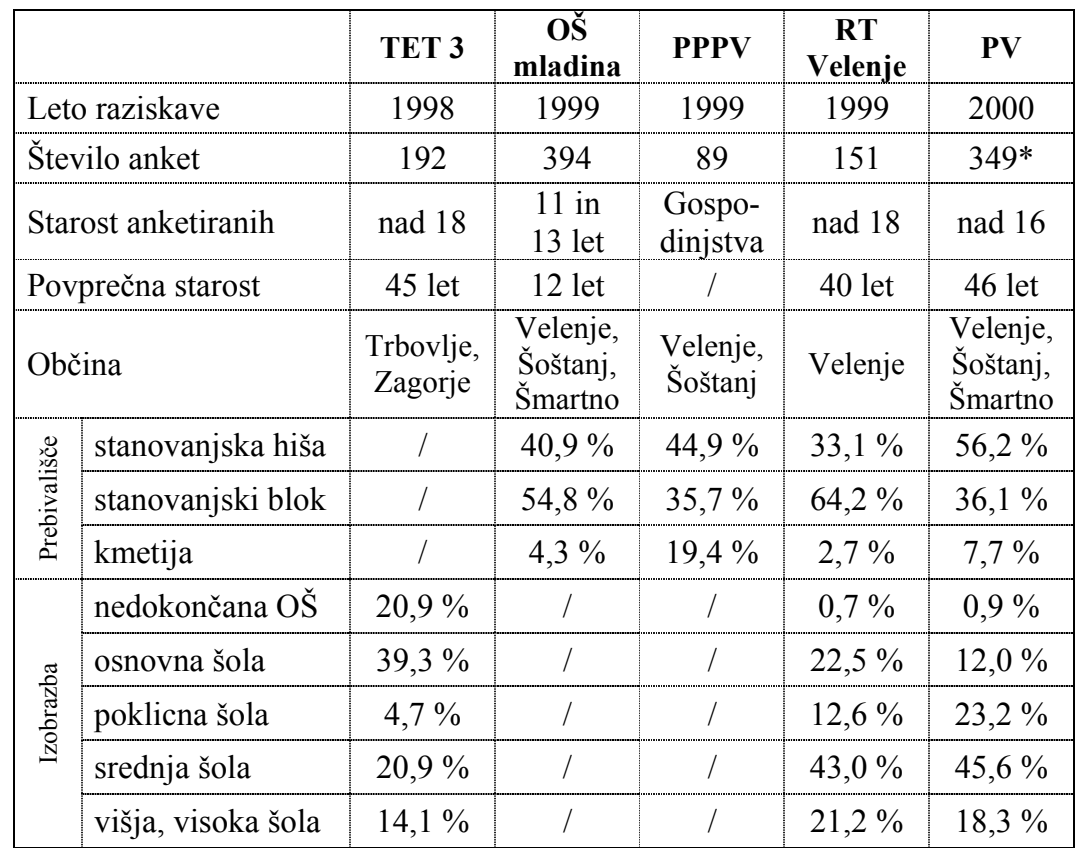

\begin{tabular}{|c|c|c|c|c|c|c|c|}
\hline & TEŠ & Gorenje & Esotech & RTH & CT & SKUPAJ \\
\hline \multicolumn{2}{|c|}{ Leto raziskave } & 2000 & 2000 & 2000 & 2001 & 2002 & \\
\hline \multicolumn{2}{|c|}{ Število anket } & $349 *$ & $349 *$ & $349 *$ & 120 & 100 & 1395 \\
\hline \multicolumn{2}{|c|}{ Starost anketiranih } & nad 16 & nad 16 & $\operatorname{nad} 16$ & $\operatorname{nad} 18$ & nad 18 & \\
\hline \multicolumn{2}{|c|}{ Povprečna starost } & 46 let & 46 let & 46 let & 43 let & 49 let & \\
\hline \multicolumn{2}{|c|}{ Občina } & $\begin{array}{l}\text { Velenje, } \\
\text { Šoštanj, } \\
\text { Šmartno }\end{array}$ & $\begin{array}{l}\text { Velenje, } \\
\text { Šoštanj, } \\
\text { Šmartno }\end{array}$ & $\begin{array}{l}\text { Velenje, } \\
\text { Šoštanj, } \\
\text { Šmartno }\end{array}$ & $\begin{array}{l}\text { Zagorje, } \\
\text { Trbovlje, } \\
\text { Hrastnik }\end{array}$ & $\begin{array}{c}\text { Trbovlje, } \\
\text { Zagorje }\end{array}$ & \\
\hline \multirow{3}{*}{ 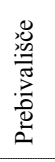 } & stanovanjska hiša & $56,2 \%$ & $56,2 \%$ & $56,2 \%$ & $31,7 \%$ & $43,0 \%$ & $41,6 \%$ \\
\hline & stanovanjski blok & $36,1 \%$ & $36,1 \%$ & $36,1 \%$ & $65,8 \%$ & $47,0 \%$ & $50,6 \%$ \\
\hline & kmetija & $7,7 \%$ & $7,7 \%$ & $7,7 \%$ & $2,5 \%$ & $10,0 \%$ & $7,8 \%$ \\
\hline \multirow{5}{*}{ 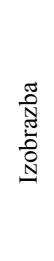 } & nedokončana OŠ & $0,9 \%$ & $0,9 \%$ & $0,9 \%$ & $3,3 \%$ & $2,0 \%$ & $5,6 \%$ \\
\hline & osnovna šola & $12,0 \%$ & $12,0 \%$ & $12,0 \%$ & $12,5 \%$ & $20,0 \%$ & $21,3 \%$ \\
\hline & poklicna šola & $23,2 \%$ & $23,2 \%$ & $23,2 \%$ & $21,7 \%$ & $19,0 \%$ & $16,2 \%$ \\
\hline & srednja šola & $45,6 \%$ & $45,6 \%$ & $45,6 \%$ & $50,0 \%$ & $35,0 \%$ & $38,9 \%$ \\
\hline & višja, visoka šola & $18,3 \%$ & $18,3 \%$ & $18,3 \%$ & $13,3 \%$ & $24,0 \%$ & $18,2 \%$ \\
\hline
\end{tabular}


Slika 1: Učenci na ogledu ugrezninskega območja v Šaleški dolini s Termoelektrarno Šoštanj v ozadju. Foto: E. Šterbenk

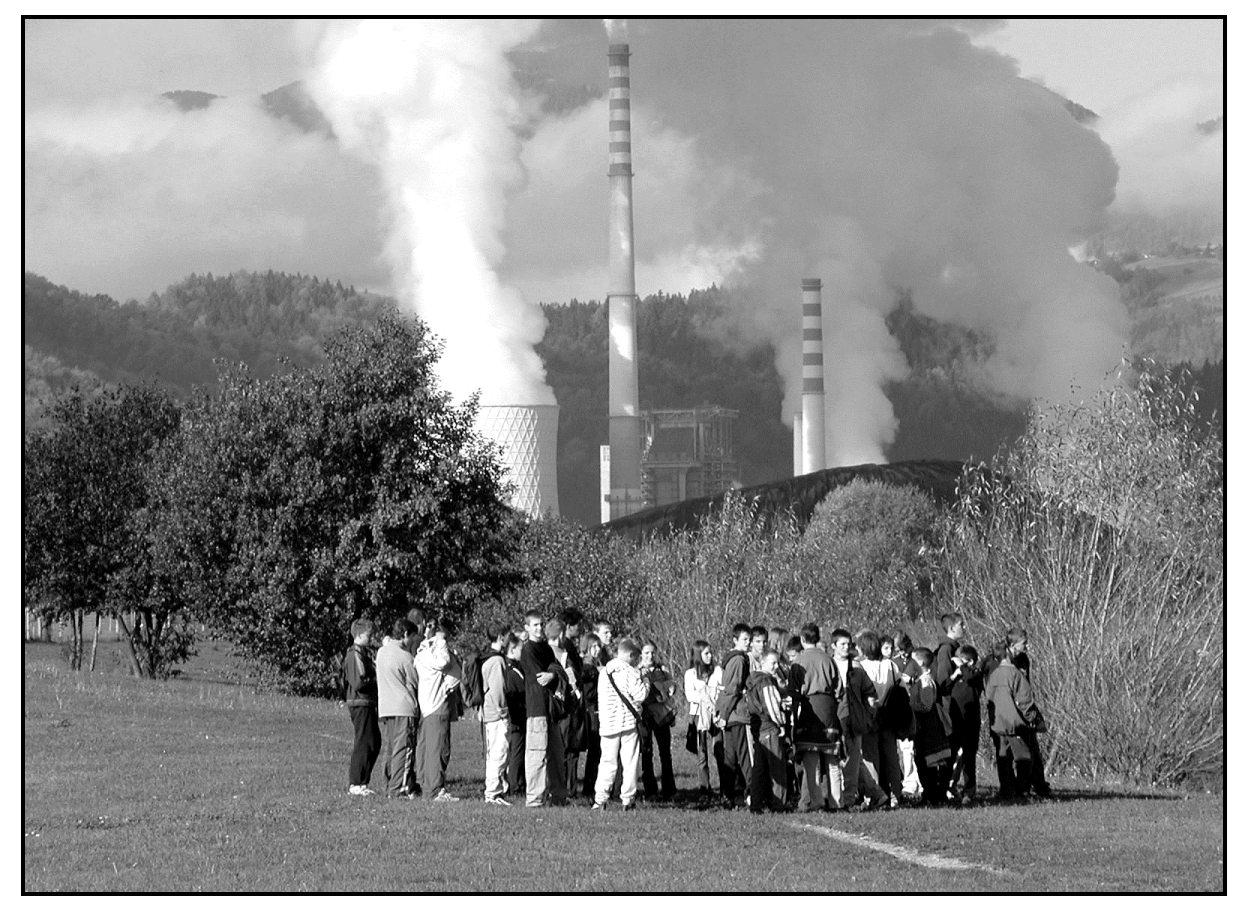

\section{REZULTATI}

Pri obravnavi in analizi anket smo se omejili na šest najpomembnejših raziskav, po tri $\mathrm{v}$ obeh regijah, katerih metodologija in ključna vprašanja so bila zastavljena enako ali zelo podobno. Ankete oz. zaključene raziskave smo primerjali med sabo. Obravnavali smo raziskave: Presoja o vplivih na okolje izgradnje Termoelektrarne Trbovlje 3 (TET 3), Raba prostora na pridobivalnem območju Rudnika Trbovlje in Hrastnik (RTH), Ocena stanja okolja v okolici Cementarne Trbovlje (CT), Osnovnošolska mladina in njen odnos do okolja v občinah Velenje, Šoštanj in Šmartno ob Paki (OŠ mladina), Odnos prebivalcev Velenja do okoljskih problemov (raziskovalni tabor Velenje) ter obsežna raziskava javnega mnenja za potrebe podjetij Termoelektrarna Šoštanj (TEŠ), Premogovnik Velenje (PV), Gorenje in Esotech. V prispevku bi bila analiza vseh vprašanj in dejstev, ki smo jih spoznali ob analizi rezultatov, nemogoča. Zato smo se orientirali le na najpomembnejša dejstva in sklepne rezultate, ki izhajajo iz opravljenih anket. Pod drobnogled smo vzeli dve klju- 
čni vprašanji, vprašanje o stanju v domačem okolju, oz. okolju v katerem živijo, in vprašanje o dinamiki onesnaževanja okolja in njegovih spremembah $\mathrm{v}$ zadnjem obdobju. Upoštevali smo obdobje zadnjih deset let.

Odziv prebivalstva na stanje okolja smo »merili« $\mathrm{z}$ vprašanjem: Ali ste zadovoljni z okoljem, v katerem živite? ter s primerjavo odgovorov $\mathrm{v}$ obeh obravnavanih regijah. Odgovor na vprašanje je pokazal, da je razlika med Zasavjem in Šaleško dolino precej velika. Medtem ko ima pozitivno mnenje o svojem okolju (z okoljem so zadovoljni ali zelo zadovoljni) v Šaleški dolini več kot tri petine anketiranih $(62,4 \%)$, je v Zasavju stanje precej slabše. S naravnim okoljem so $\mathrm{v}$ Zasavju manj zadovoljni, saj jih je pozitivno na to vprašanje odgovorilo le $39,5 \%$. Zanimivo je, da so med anketiranimi na to vprašanje najbolj pozitivno odgovarjali mladi v Šaleški dolini, ki še niso toliko obremenjeni z okoljskimi vprašanji.

Najbolj so si deleži nasprotujoči v kategorijah zelo zadovoljen in zelo nezadovoljen. Delež »zelo zadovoljnih z domačim okoljem« je v Šaleški dolini trikrat večji kot v Zasavju, prav tako je trikrat manjši delež »nezadovoljnih« v primerjavi zasavskega okolja z okoljem Šaleške doline.

Preglednica 2: Odziv prebivalcev na stanje okolja: Ali ste zadovoljni z okoljem, $v$ katerem živite?

\begin{tabular}{|lcccc|c|}
\hline raziskava & $\begin{array}{c}\text { število } \\
\text { anket }\end{array}$ & $\begin{array}{c}\text { zelo } \\
\text { zadovoljen }\end{array}$ & $\begin{array}{c}\text { odstotni delež (\%) } \\
\text { zadovoljen }\end{array}$ & nezadovoljen & $\begin{array}{c}\text { zelo } \\
\text { nezadovoljen }\end{array}$ \\
\hline TET & 192 & 5,2 & 38,0 & 45,5 & 11,3 \\
RTH & 120 & 2,5 & 46,7 & 40,0 & 10,8 \\
CT & 100 & 3,0 & 23,0 & 41,0 & 33,0 \\
\hline Zasavje & $\mathbf{4 1 2}$ & $\mathbf{3 , 6}$ & $\mathbf{3 5 , 9}$ & $\mathbf{4 2 , 2}$ & $\mathbf{1 8 , 3}$ \\
\hline OŠ mladina & 392 & 20,4 & 56,9 & 20,7 & 2,0 \\
RT Velenje & 151 & 10,6 & 53,0 & 28,5 & 7,9 \\
PV, TEŠ, Gorenje, & 349 & 0,6 & 45,8 & 45,3 & 8,3 \\
Esotech & $\mathbf{8 9 2}$ & $\mathbf{1 0 , 5}$ & $\mathbf{5 1 , 9}$ & $\mathbf{3 1 , 5}$ & $\mathbf{6 , 1}$ \\
\hline Šaleška dolina & $\mathbf{8 9 2}$ & & & \\
\hline
\end{tabular}

Dejstvo je, da se je onesnaženost naravnega okolja v Šaleški dolini zmanjšala bolj kot v Zasavju ter da je okoljska sanacija termoenergetskih objektov v Šaleški dolini zaključena, v Zasavju pa še ne. To sta nedvomno dejavnika, ki sta najpomembnejša v odzivanju anketiranih na ta vprašanja. Če k temu dodamo tudi boljše reševanje socialnih in gospodarskih problemov v Šaleški 
dolini, manjših problemov $\mathrm{v}$ gospodarski tranziciji in boljšo infrastrukturno urejenost, rezultati pravzaprav niso presenetljivi.

Grafikon 1: Ali ste zadovoljni z okoljem v Zasavju?

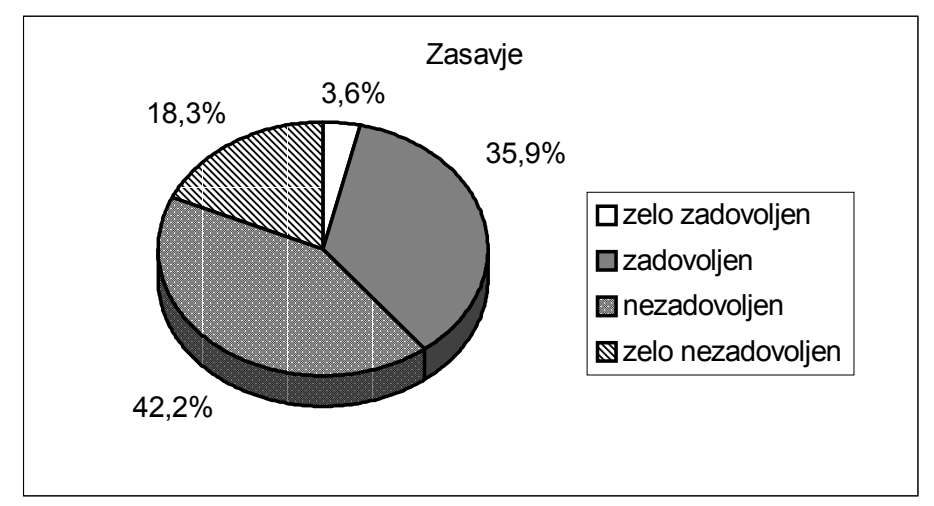

Grafikon 2: Ali ste zadovoljni z okoljem v Šaleški dolini?

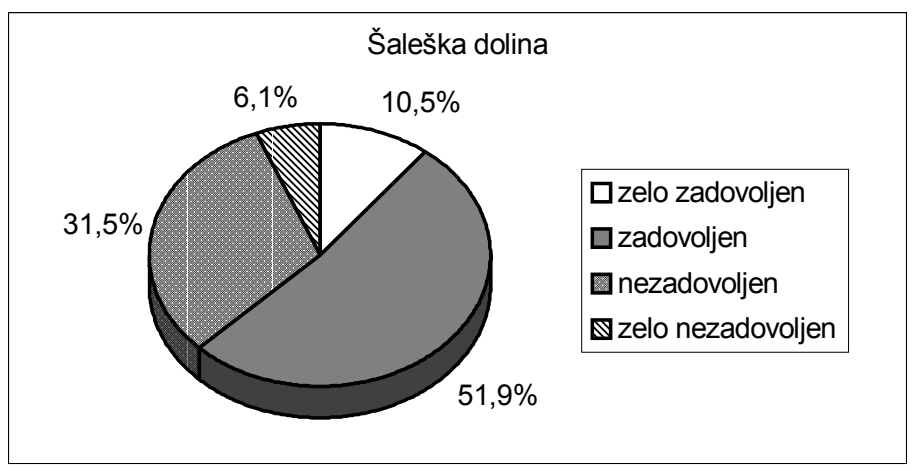

Drugi sklop vprašanj, ki smo ga vzeli pod drobnogled, se je nanašal na dinamiko onesnaževanja okolja $\mathrm{v}$ obeh obravnavanih regijah. Zanimalo nas je stališče anketiranih do onesnaževanja $\mathrm{v}$ zadnjem desetletju. Razlike $\mathrm{v}$ odgovorih $\mathrm{v}$ primerjavi z vprašanjem o stanju okolja niso tako velike kot $\mathrm{v}$ prejšnjem vprašanju, predvsem iz razloga, da se kljub okoljskim izboljšavam globalno stanje v okolju slabša. Zanimivo je, da kljub večjim, obsežnejšim in hitrejšim sanacijskim posegom v Šaleški dolini »močnejše zmanjševanje onesnaženosti« opažajo predvsem v Zasavju, kategorija »manjše zmanjšanje onesnaženosti« pa je večja v Šaleški dolini. To si lahko razlagamo tudi z večjo intenziteto 
onesnaževanja kotlinskega obrobja v preteklosti v primeru Šaleške doline ter zmanjšanja danes, z izgradnjo razžveplalnih naprav v TEŠ-u in na drugi strani zmanjšanih imisij in izboljšav stanja $\mathrm{v}$ dolinskem delu Zasavja (npr. toplifikacija), kljub ne bistveno zmanjšanim emisijam v okolje.

Preglednica 3: Dinamika spreminjanja okolja: Ali se je onesnaženost v vašem okolju v zadnjem času spremenila?

\begin{tabular}{|l|c|c|c|c|c|}
\hline \multirow{2}{*}{ raziskava } & \multirow{2}{*}{\begin{tabular}{c}
\multirow{2}{*}{ antevilo } \\
anket
\end{tabular}} & narašča & $\begin{array}{c}\text { ni spre- } \\
\text { memb }\end{array}$ & $\begin{array}{c}\text { malo } \\
\text { zmanjšala }\end{array}$ & $\begin{array}{c}\text { močno } \\
\text { zmanjšala }\end{array}$ \\
\cline { 5 - 6 } & 192 & 43,0 & 38,0 & 19,0 & 0 \\
\hline TET & 120 & 13,3 & 6,7 & 60,0 & 20,0 \\
\hline RTH & 100 & 32,0 & 20,0 & 45,0 & 3,0 \\
\hline CT & $\mathbf{4 1 2}$ & $\mathbf{2 9 , 4}$ & $\mathbf{2 1 , 6}$ & $\mathbf{4 1 , 3}$ & $\mathbf{7 , 7}$ \\
\hline Zasavje & 392 & 18,5 & 36,8 & 41,1 & 3,6 \\
\hline OŠ mladina & 151 & 28,5 & 20,5 & 47,7 & 3,3 \\
\hline RT Velenje & 349 & 17,8 & 6,6 & 71,9 & 3,7 \\
\hline $\begin{array}{l}\text { PV, TEŠ, Gorenje, } \\
\text { Esotech }\end{array}$ & $\mathbf{8 9 2}$ & $\mathbf{2 1 , 6}$ & $\mathbf{2 1 , 3}$ & $\mathbf{5 3 , 6}$ & $\mathbf{3 , 5}$ \\
\hline Šaleška dolina & & & &
\end{tabular}

Grafikon 3: Dinamika onesnaženosti okolja z vidika anketiranih

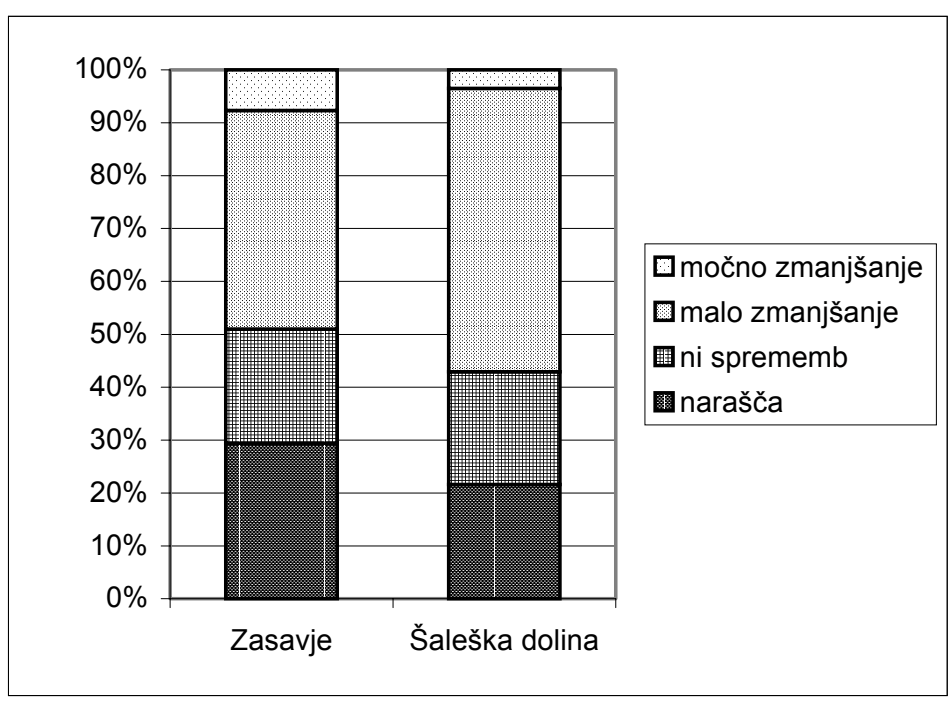


Kljub temu da formalna primerjava stanja okolja $\mathrm{v}$ obeh regijah ni primerljiva zaradi različnih pokrajinskih značilnosti obeh regij, nam z vidika dinamike veliko pove dejstvo, da se je za trend pozitivnega stanja okolja, kategorijo »močno in manjše zmanjšanje onesnaženosti«, v Šaleški dolini izreklo več kot polovico anketiranih $(57,1 \%)$. V Zasavju je ta delež manjši od polovice $(49,0 \%)$. Hkrati je to dovolj velik kazalec dinamike spreminjanja okolja in stanja, $\mathrm{s}$ katerega gledajo anketirani na spremembe. Dejavniki, ki so pomembni in ki kažejo v obeh primerih na usmerjenost ljudi v območjih raziskave, so prav gotovo strah pred neznanim, pozitivna usmerjenost in razvojna naravnanost ipd.

$\mathrm{Ob}$ analizi vseh anket in prebiranju pripomb in predlogov anketiranih bi lahko izpostavili še vrsto drugih problemov. Mnogi izmed njih so lokalne narave (lokalno onesnaževanje) $\mathrm{v}$ obeh območjih, pojavlja pa se tudi vrsta socialnih in gospodarskih vprašanj, ki so tako ali drugače povezana z okoljsko problematiko. Obravnava vseh bi zahtevala bolj poglobljeno in obsežnejšo analizo. Pa vendar lahko rezultate ostalih vprašanj in vrsto podatkov združimo $\mathrm{v}$ nekaj bistvenih značilnosti in opažanj, pridobljenih z raziskavami. Združimo jih lahko v naslednje točke:

- Prebivalci Šaleške doline so do onesnaževanja zelo kritični in so s svojim okoljem večinoma zadovoljni. V Zasavju so prebivalci s svojim okoljem manj zadovoljni, ker je njihovo okolje glede na slovenske razmere še vedno nadpovprečno obremenjeno.

- Zaradi ostalih nerešenih problemov (socialni in gospodarski problemi, neurejena infrastruktura etc.) so prebivalci Zasavja do stanja v okolju manj kritični. O stanju okolja bodo razmišljali intenzivneje takrat, ko bo ta problematika bolje urejena.

- Največji problem se prebivalcem Šaleške doline še vedno zdi onesnaževanje zraka in problemi, povezani z njim (npr. težave z dihali). Skrbi jih tudi povečevanje prometa in s tem povezano onesnaževanje. Največji problem predstavlja tudi anketiranim v Zasavju onesnaževanje zraka, sledi pa slaba komunalna opremljenost in splošno onesnaženje (neurejenost okolice, hrup etc.).

- V Zasavju so bili anketirani mnenja, da se stanje v okolju zadnja leta ni bistveno spremenilo; najbolj vidni pozitivni učinki so pri sanaciji ugreznin, najslabše pa je stanje v okolici Cementarne. Največje pozitivne spremembe so bile v Šaleški dolini storjene na področju čiščenja dimnih plinov v Termoelektrarni Šoštanj in s sanacijo rudarskih ugreznin.

- Pozitiven socialni in gospodarski vpliv naročnikov raziskav (Premogovnik Velenje, Rudnik Trbovlje in Hrastnik, Termoelektrarna Šoštanj, Termoelektrarna Trbovlje, Cementarna Trbovlje, Gorenje Velenje, Esotech Velenje) v prvi vrsti predstavlja delo oz. zaposlitev in delovno mesto. 
- Zaključki ekoloških sanacij so v Šaleški dolini premalo poznani in odmevni ter slabo predstavljeni (mediji, okoljska vzgoja etc.).

- Prebivalci zahodnega dela Šaleške doline, kjer je bilo predvideno nadaljnje širjenje pridobivalnega prostora premogovnika Velenje, so imeli zelo odklonilen odnos do predvidenega posega (dodatna obremenitev pokrajine s podzemnim odkopom lignita).

Večina kazalcev odnosa do okolja in stanja okolja v percepciji anketiranih je bila predstavljena in metodološko zastavljena za odraslo populacijo. Pri mladini pa je zaradi specifičnosti raziskave vendarle izstopalo nekaj dejstev, ki bodejo v oči. Učenci šestih in osmih razredov vseh devetih osnovnih šol iz Velenja (6), Šoštanja (2) in Šmartnega ob Paki (1) ne mislijo vedno podobno kot njihovi starši, sosedi ... In kaj je torej značilno za njih, ki okolje in okoljske probleme šele spoznavajo?

- Učenci nižjih razredov stopnje razredne stopnje (6. razred) so do stanja okolja bolj kritični kot učenci višjih razredov (8.razred).

- Starejši gledajo bolj pozitivno na dinamiko spreminjanja okolja.

- Učenci so mnenja, da šola premalo okoljsko izobražuje in premalo poudarja okoljsko tematiko.

- Negativne trende v okolju in spremembe stanja okolja bolj opažajo učenci manj obremenjenih območij, kjer se stanje okolja slabša zaradi globalnih sprememb.

- Okoljska problematika bolj zanima učence najbolj obremenjenih območij.

- Učenci so kot vir okoljskih informacij postavili šolo šele na 4. mesto (za elektronskimi mediji, domom in tiskanimi mediji).

\section{SKLEP}

Poleg vrste zanimivih rezultatov se nam ob analizi porajajo in odpirajo tudi druga vprašanja in misli, ki so na svoj način nadaljevanje nekdanje okoljske miselnosti.

»Zlata leta« okoljskih gibanj in iskrenega zanimanja za okolje in okoljska vprašanja so minila, tudi v Zasavju in Šaleški dolini. S tem seveda ni nič narobe, narobe je morda to, da se je pojem zaznavanja okoljskih problemov reduciral le na vprašanja, kot so »kolikšno rento bomo izterjali« in »tega nočemo imeti pred svojim pragom «, čeprav je stanje na dvorišču takšno kot nekoč ali še slabše in čeprav renta ne služi vzpostavitvi prvotnega ali sonaravnega stanja.

Danes je prišel čas, ko moramo v okoljskem smislu delati majhne in trdne korake, še bolj misliti globalno in delovati lokalno, tudi zato ker je okoljska 
sanacija velikih termoenergetskih objektov v Sloveniji pred zaključkom. V našem primeru pa tudi zato, ker Zasavje in Šaleška dolina kljub vsem prizadevanjem in uspehom okoljskih sanacij ne bosta nikoli več takšni, kot sta bili. Naloga vsakega od nas je, da vzgaja, izobražuje, varčuje, ločeno zbira odpadke ...

\section{Literatura:}

Kotnik, K., 2002, Ocena stanja okolja v okolici Cementarne Trbovlje - psihosocialni in ekonomski vidik, v: Flis, J. s sod., Ocena stanja okolja v okolici Cementarne Trbovlje, delovno poročilo št. 5/02/02, 18. str., ERICo Velenje.

Šalej, M., 1999, Osnovnošolska mladina in njen odnos do okolja v občinah Velenje, Šoštanj in Šmartno ob Paki, delovno poročilo št. 206/2000, 44 str. s pril.ERICo Velenje.

Šalej, M., 1999, Historično-geografski oris Šaleške doline in njenega obrobja (Geografsko okolje kot zgodovinski sooblikovalec kulturne pokrajine), v: Velenje - razprave o zgodovini mesta in okolice, zbornik, ur. Ravnikar, T., založila: Mestna občina Velenje, str. 10-37.

Šalej, M., 2001, Odnos prebivalcev Velenja do okoljskih problemov, v: Šalej, M., Zbornik Velenje 1999/2000, Okolje 4. zvezek, ERICo Velenje, str. 196-209.

Šalej, M., 2001, Raba prostora na pridobivalnem območju RTH in odnos prebivalcev občin Trbovlje in Hrastnik do okolja - javnomnenjska raziskava, v: Pokorny, B. s sod., Strokovne podlage za rabo prostora na pridobivalnem območju Rudnika Trbovlje in Hrastnik, delovno poročilo št. 16/02/01, 29 str. s pril., ERICo Velenje.

Šalej, M., Špeh, N., 2000, Javno mnenje o ravnanju Premogovnika Velenje do okolja : odnos prebivalstva do okolja in Premogovnika Velenje na območju Šaleške doline - javnomnenjska raziskava, delovno poročilo št. 206/2000, 47 str. s pril., ERICo Velenje.

Šalej, M., Špeh, N., 2000, Odnos prebivalcev Šaleške doline do Termoelektrarne Šoštanj in okolja - javnomnenjska raziskava, delovno poročilo št. 229/2000, 49 str. s pril.ERICo Velenje.

Špeh, N., Šalej, M., 2000, Javnomnenjska raziskava - Odnos prebivalcev na območju UE Velenje do podjetja Gorenje d.d. in okolja, delovno poročilo št. 166/2000, 31 str. s pril., ERICo Velenje.

Špeh, N., Šalej, M., 2000, Javnomnenjska raziskava - odnos prebivalcev na območju UE Velenje do podjetja ESOTECH in okolja, delovno poročilo št. 153/2000, 20 str. s pril., ERICo Velenje. 
Špes, M., 1997, Družbenogeografski vidik proučevanja okoljskih problemov, Geografski vestnik 69, Časopis za geografijo in sorodne vede, Zveza geografskih društev Slovenije, Ljubljana, str. 187-202.

Špes, M., 1998, Poročilo o vplivih na okolje nadomestnega objekta TET 3, psihosocialni vidik, v: Flis, J. s sod., Poročilo in ocena o vplivih na okolje nadomestnega objekta TET 3, delovno poročilo, 21 str., ERICo Velenje.

\title{
INHABITANTS' RESPONSE TO THE LOCAL ENVIRON- MENT AND ITS PROBLEMS IN THE CASE OF THE ŠALEK VALLEY AND THE ZASAVJE REGION
}

\begin{abstract}
Summary
The Šalek Valley and the Zasavje Region are the most important regions in Slovenia where electrical energy is produced by thermal power plants. Coal mines are located in both regions and thez represent the main source of coal for the Ššstanj Thermal Power Plant and the Trbovlje Thermal Power Plant. The Šoštanj Thermal Power Plant is the largest producer of electricity in Slovenia in the last decades and is located in the Šalek Valley. The Trbovlje Thermal Power Plant is located in the centre of the Zasavje Region with the longest coal mining tradition in the country. Almost all the coal that is mined in both coal mines is used in thermal power plants. The coal mines also cause landscape subsidence meanwhile the thermal power plants are the major sources of air pollution in Slovenia.

In this paper we focused attention to the response of the inhabitants from the both regions to the local environment and its problems. We used a questionnaire to survey how inhabitants of the communes Velenje, Šoštanj, Šmartno ob Paki, Trbovlje, Hrastnik and Zagorje ob Savi (Šalek Valley and Zasavje Region) respond to environmental problems in their regions. The answers of 1395 inhabitants of all ages were analyzed. The main aim of our study were following: to estimate the pollution severity and environmental conditions, to compare the answers between both regions and to compare their points of view. Basic conclusions are:

- The inhabitants of the Šalek Valley are very critical toward their environment and they are basically satisfied with it $(62,4 \%)$. In the Zasavje Region inhabitants are less satisfied $(39,5 \%)$ with their environment, because the pollution of their region is larger than average in Slovenia.

- Because of the social and economical problems in region, inhabitants of the Zasavje Region are less critical toward the environmental problems.
\end{abstract}


- The main problems in both regions are air pollution and problems linked with it. The second problem by inhabitants' points of view is traffic density in the Šalek Valley, meanwhile in the Zasavje Region the second main problem is defective commune infrastructure and general pollution of the area.

- The inhabitants opinion in the Zasavje Region is, that no progress in the environmental condition were made in the last decade. The positive changes, in the inhabitants viewpoint, in the last time were made with the sanation and recultivation of subsidence surface in both regions. Main achievement was made in the Šoštanj Thermal Power Plant (Šalek Valley) with the desulphurization device to purify the chimney stack gases.

- According to the analyses it is necessary to devote more attention to environmental improvement in the Zasavje Region and to environmental education and environmental school projects. 